\title{
Research in Religion on the Political Agenda A Swiss National Research Programme on Religion and Its Implications
}

\author{
Christoph Morgenthaler, ${ }^{a}$ David Plüsss ${ }^{b} \&$ Carl Sterkens ${ }^{c}$ \\ a) University of Bern, Switzerland \\ b) University of Bern, Switzerland \\ c) Radboud University Nijmegen, the Netherlands \\ Corresponding author: Christoph.Morgenthaler@theol.unibe.ch \\ Received 20 August 2011; accepted 15 October 2011
}

\begin{abstract}
This introductory article for this special issue of the Journal of Empirical Theology, sketches the political and societal context in which the Swiss National Research Programme on "Religion, State, and Society" was developed and gives a general overview of this research programme. First, it introduces recent developments in Switzerland's religious landscape and illustrates their relevance for the development of a broad state-funded research programme on religion. The authors reflect on Switzerland's understanding of religious neutrality which has been both questioned and reactivated due to increased religious plurality in Switzerland. While interdisciplinary approaches open new possibilities for research on religion, theology seems to be perceived as manifesting an 'ecclesiastical captivity'. Consequently, theology clearly plays a secondary role in interdisciplinary research programmes. The impending marginalisation of theology, even in the realm of its main research competence, is forcing theological disciplines to position themselves in a new way.
\end{abstract}

\section{Keywords}

Swiss National Research Programme, religious plurality in Switzerland, theology and interdisciplinarity

\section{Introduction}

Switzerland's religious landscape has undergone deep changes during the past few decades. Immigrants brought a number of non-Christian religions with them. Affiliation to Christian Churches has become looser and the number of people with no religious affiliation is rising. According to the Swiss Federal Statistical Office (www.bfs.admin.ch) Switzerland is anno 2000 still a predominantly Christian society with $73.8 \%$ membership in the two large 
Churches (41.8\% Roman Catholic, 33.0\% Reformed Christians, 1.8\% Orthodox and $0.2 \%$ Old Catholic). The members of the second largest group (11.1\% of the population) indicate that they do not belong to any religious organization. Muslims represent the third largest religious group in Switzerland with $4.3 \%$ of the population. Buddhists $(0,3 \%)$, Hindus $(0.4 \%)$ and Jews $(0,2 \%)$ are the smallest groups with a distinct religious affiliation. About $4.3 \%$ of the Swiss population did not respond to the question whether they belong to any religious denomination (Bovay \& Broquet 2004, 11).

Data from 22 surveys and the population censuses of 1970, 1980, 1990 and 2000 show that the number of people belonging to the Catholic and Reformed Churches has been decreasing continuously during the last decades (estimation for 2009: Catholic 31\%, Protestant 32\%). On the other hand the proportion of members of other, mostly non-Christian religions is increasing steadily (today approx. $12 \%$ of the population). Most important is the increase of persons with no religious affiliation from $1 \%$ to $25 \%$ of Swiss residents during the last 40 years, with a strikingly strong increase in the last ten years (Stolz et al. 2011, 5ff).

The large Catholic and Reformed Churches are still considered to be established Churches (Volkskirchen) and are institutionalised accordingly. Switzerland does not have a state religion, nor are there regulations for the recognition or support of religious institutions on the national level. But there are specific regulations on the relationship between Church and state on the level of the 26 Swiss cantons. These federal cantons differ widely in size, both in area and population (Church 2004). Consequently, cantonal structures differ widely, as does the legal position of specific religious denominations within them (cf. Rutz 2001). In most Swiss cantons, the mainline Churches are officially approved as public corporations by the government under the condition that they have some form of democratic organisation ('Church parliament'), that their finances are open to public scrutiny, and under the assumption that they contribute to the good of society. In 18 out of 26 cantons, predominantly in central and Eastern Switzerland, taxes for the major religions are collected in together with the state taxes by the cantonal authorities (up to $2.3 \%$ of the gross income), although the taxation systems and the amounts vary hugely by canton. In most of these cantons individuals as well as companies are taxed. In the cantons of Western Switzerland, however, there is generally a stricter separation of Church and state, and Church taxes are no longer collected by the cantonal authorities. Even though the Catholic and Reformed Churches can be considered Volkskirchen that can count on a wide societal support, the taxation system comes increasingly under pressure. In Neuchâtel, for instance, the percentage of people paying their non-compulsory Church tax has fallen by 
half over the past forty years. And as far as taxation of firms is concerned, cigarette company Philip Morris made headlines by opting not to pay the voluntary Church tax in canton Neuchâtel in 2010 (Bradley 2010). More recently, in April 2011, a self-employed software engineer applied to the European Court of Human Rights in response to being obliged to pay Church tax in the canton of Schwyz, after the Swiss Federal Court in Lausanne had ruled that the taxation policy was not in violation of religious freedom in September 2010. Even if these cases may not be considered as outright indicators of an ongoing secularisation in Switzerland, then they may be seen at least as visible signs of the decline in public acceptance the mainline Churches have suffered.

The variety of ways that Churches are organised in the different cantons mirrors the wide variety in religious orientations of the individual Swiss citizens. Stolz et al. (2011) developed a typology of religious orientation distinguishing four types of Church members: 'institutional' (believing and belonging), 'alternative' (believing without belonging), 'distanced' (belonging without believing) and 'secular' (neither belonging nor believing). This typology illustrates that the historical ties between Church and belief (on the level of the individual), and between Church and religious institutionalization (on the level of the religious organisations) are becoming weaker. Switzerland does not differ in this respect from most other European countries. There is unbelief among Church members and belief among non-members, and religious institutionalisation can be found inside and outside the traditional mainline Churches. In the Swiss established Churches the 'institutional' group represents $23 \%$ of the members in the Catholic and $15 \%$ in the Reformed Churches. The vast majority of the members are distanced (Catholics 66\%, Reformed $70 \%$ ). Conversely, in the free Churches (small, independent Churches such as the Methodists or Pentecostals with a protestant background) $85 \%$ of the members are 'institutional' and 15\% 'distanced' (cf. Portmann \& Plüss in this volume).

\section{The Swiss National Research Programme "Religion, the State, and Society"}

These times of change in the religious domain lead to a number of questions. What is the impact of the changes in religious commitment on the private and public sphere in Switzerland? How can religious minorities be integrated into public life, economically, politically and culturally? Will conflicts about religious issues become more frequent with increased religious plurality? What is the role of the state regarding the regulation of the relations between the 
dominant denominations, but also between Christian religious communities and religious communities with a non-Christian background and a different ethnic origin? Should the role the government(s) play be re-defined? These questions lead to the formation of a Swiss national research programme on "Religion, the State, and Society" (National Research Programme 58). ${ }^{1}$

The programme was planned to subject changes in Switzerland's religious makeup to scientific scrutiny and to generate insights of practical relevance for the authorities, policymakers, schools and religious communities promoting communication and understanding among the various religious communities, as well as between the religious communities and non-religious people. For this purpose, a research framework with six modules was designed. Each module contained between 3 and 7 research projects.

Module 1 (Religious Pluralism and Swiss Society) was comprised of projects analysing Switzerland's religious minorities, like Tamil Hindus, Vietnamese and Tibetan Buddhists, Jews and Orthodox Christians. How can these religious minorities preserve their traditions and, at the same time, adapt to the changes that have taken place in the Swiss context? Module 2 (Muslims in Switzerland) addressed questions concerning Switzerland's largest religious minority, namely the various Muslim denominations. How do Switzerland's Muslim communities present themselves to the public? How do they uphold their own specific interests? Projects of module 3 (Religions in Public Institutions) clarified the role played by religion in various secular areas of public life (e.g. education, health and social sector) and assessed the benefits and costs of religious communities in Switzerland. Module 4 (Young People, School and Religion) was devoted to young people's attitudes towards religion, their religious upbringing and education, as well as the role of religion in the development of individual identity. Module 5 (Forms of Religious Life) addressed individual attitudes towards religion, as well as the collective structuring of the Swiss religious landscape in comparison to that of other countries. Module 6 (Religion, Media and Politics) explored the public presence of religion both in society and in the political sphere with a special focus on the role of the media.

The call for research proposals resulted in 120 research applications fitting into one of these modules. After a two-step international peer review process,

\footnotetext{
${ }^{1}$ National research programmes are approved and funded by the government, the Swiss Federal Council, on urgent problems of national importance. Implementation of these research programmes includes support of practical application of research findings in policymaking and society. The NRP 58 was approved by the Federal Council in December 2005, followed by a call for applications in September 2006. The running time of the granted projects was from end 2007 until 2011. More information about the research programme, as well as the final reports of all the projects, can be found on the website of the NRP 58: www.nfp58.ch.
} 
28 projects were funded. Most of them were realized in a period of 3 years (2007-2010) by academic research teams. Because of their academic embedding, most projects can be located in a specific research discipline within the humanities and/or social sciences. Needless to say, quite often an interdisciplinary approach proved to be more fruitful or even necessary: 13 of the selected projects originate in the disciplines of religious studies and/or theology, 7 in sociology, 3 in political science, 2 in media studies, 1 each in social anthropology, psychology and economics. The NRP 58 research programme had a total budget of about 7,000,000 Swiss Francs (5,655,000 Euros), distributed over the 28 projects granted. An overview of modules and projects can be found in Table 1.

Table1: Overview of the projects in the Swiss National Research Programme 58: Religion, the State and Society'

\begin{tabular}{|l|l|}
\hline \multicolumn{2}{|l|}{ Module 1: Religious Pluralism and Swiss Society } \\
\hline $\begin{array}{l}\text { The public presence and changes in the gender } \\
\text { roles of Tamil Hindus and Vietnamese Buddhists in } \\
\text { Switzerland }\end{array}$ & Religious studies \\
\hline How Jewish life in Switzerland is changing & Jewish studies \\
\hline $\begin{array}{l}\text { Orthodox religious communities in Switzerland: } \\
\text { reasons for their successful integration }\end{array}$ & Sociology \\
\hline $\begin{array}{l}\text { The perception of Tibetan Buddhism in Swiss } \\
\text { institutions }\end{array}$ & Religious studies \\
\hline Second and third-generation Tibetans in Switzerland & Religious studies \\
\hline Module 2: Muslims in Switzerland & \multicolumn{2}{|l|}{} \\
\hline $\begin{array}{l}\text { How Bosnian and Albanian Muslims in Switzerland } \\
\text { are reacting to the Islam discourse }\end{array}$ & Religious studies \\
\hline $\begin{array}{l}\text { How is Islam organized in Swiss society? } \\
\text { Muslims in Switzerland - torn between recognition } \\
\text { as a minority and accommodation }\end{array}$ & $\begin{array}{l}\text { Political science } \\
\text { international studies }\end{array}$ \\
\hline $\begin{array}{l}\text { Training Imams and religious teachers in } \\
\text { Switzerland? }\end{array}$ & $\begin{array}{l}\text { Oriental studies, } \\
\text { religious studies }\end{array}$ \\
\hline Muslim diaspora communities in Switzerland & Social Anthropology \\
\hline
\end{tabular}


Table 1 (cont.)

\begin{tabular}{|c|c|}
\hline \multicolumn{2}{|l|}{ Module 3: Religions in Public Institutions } \\
\hline Religious pluralism in Switzerland's prisons & Sociology and pedagogy \\
\hline The costs and benefits of Churches in Switzerland & Economics \\
\hline Religion and health behaviour of the elderly & Gerontology \\
\hline Social work driven by the divine spirit? & Social work \\
\hline Teacher training - a job or a vocation? & Teacher training \\
\hline \multicolumn{2}{|l|}{ Module 4: Young People, School and Religion } \\
\hline $\begin{array}{l}\text { Religion and ethnicity — a survey among young } \\
\text { adults }\end{array}$ & Sociology \\
\hline $\begin{array}{l}\text { Migration and religion and how these are perceived } \\
\text { by children and young people in Switzerland }\end{array}$ & Social anthropology \\
\hline $\begin{array}{l}\text { Religious education between the state and religious } \\
\text { communities }\end{array}$ & Religious studies \\
\hline What values and religion mean to young adults & $\begin{array}{l}\text { Theology and } \\
\text { psychology }\end{array}$ \\
\hline \multicolumn{2}{|l|}{ Module 5: Forms of Religious Life } \\
\hline Secularized Christians and religious diversity & Theology \\
\hline Local religious groupings in Switzerland and the US & Religious studies \\
\hline Individual religiosity in times of social change & $\begin{array}{l}\text { Religious studies/ } \\
\text { Sociology of religion }\end{array}$ \\
\hline \multicolumn{2}{|l|}{ Module 6: Religion, Media and Politics } \\
\hline $\begin{array}{l}\text { The role of the mass media in the "clash of } \\
\text { civilizations» }\end{array}$ & Media Studies \\
\hline $\begin{array}{l}\text { Religious difference as a problem in political } \\
\text { discourse }\end{array}$ & $\begin{array}{l}\text { Media studies, } \\
\text { sociology }\end{array}$ \\
\hline $\begin{array}{l}\text { What is the role of religious communities in } \\
\text { plebiscites? }\end{array}$ & $\begin{array}{l}\text { Theology, sociology of } \\
\text { religion }\end{array}$ \\
\hline $\begin{array}{l}\text { Controversies concerning visible symbols of religious } \\
\text { identity }\end{array}$ & Religious studies \\
\hline $\begin{array}{l}\text { How religion and religious communities are depicted } \\
\text { on television }\end{array}$ & Media studies \\
\hline Protecting religious minorities in a direct democracy & Political science \\
\hline
\end{tabular}


This special issue of JET presents four projects, out of three of the five research modules. A first research project, headed by Morgenthaler \& Käppler, studied the importance of religion and value orientations for the emergent identities and mental health of adolescents (age 13-16) from different religious backgrounds, thus illuminating the changed context of religious education. Some major results of this project are published in the first article by Brodbeck et al., Adolescents' Values and Value-based Reasoning in Intercultural Dilemma Situations. The other projects presented here deal with the emerging interest in "visible religion" in its varied forms of negotiating religion in the public sphere. The second article by Portmann \& Plüss, Good Religion or Bad Religion: Distanced Church-Members and their Perception of Religion and Religious Plurality, describes how secularized Christians perceive religions - foreign religions as well as their own - in the public sphere and how they deal with the social and religious diversity of contemporary society. The article by Dahinden et al. discusses the Representation of Islam and Christianity in the Swiss Media. Their focus is on the role of the mass media and their (un)fair and/or (un)prejudiced reporting of religious news items. Using topical examples such as the headscarf debate and the minaret controversy, their research examined the influence of visible symbols of religious identity on perceptions of cultural difference and foreignness in a pluriform society, as well as the way religious traditions organize themselves to influence media exposure. Finally, Grigo focuses on the relevance and consequences of visibility of religious identity by means of religiously connoted clothing. In Visibly Unlike: Religious Dress between Affiliation and Difference, Grigo bases herself on six case studies to emphasize that visual, respectively embodied, (religious) difference is both relevant and loaded with ambiguities for members of different religious communities.

As interesting as the single research projects and their results were the conceptualisation, realisation and dynamics of such a state-run research programme on religion. We try to highlight briefly a few points that are relevant for research on religion and which might be of interest to the readers of this special issue. The following observations and remarks are mainly made from the discipline of Christian theology, a discipline traditionally associated with the study of religion, but only marginally integrated in the NRP 58 (2 of the 28 research projects originated in theology). ${ }^{2}$ Comments from a social-scientific

2 Interesting in itself is to compare NRP 58 with other broadly invested national and transnational research programmes trying to stimulate collaborative research across the arts, humanities, social sciences and law, such as: 'The Religion and Society Research Programme' in the United Kingdom (www.religionandsociety.org.uk); 'The Future of the Religious Past' in the Netherlands (www.nwo.nl/future); 'The Role of Religion in the Public Sphere' in the five Nordic countries Denmark, Norway, Sweden, Finland, and Iceland (www.kifo.no); the Cluster of Excellence of the Deutsche Forschungsgemeinschaft on 'Religion and Politics' in Germany (www.uni-muenster. de/Religion-und-Politik); or 'Religious Diversity and Secular Models in Europe - Innovative 
perspective or of that of religious studies on the NRP 58 (11 projects) might be markedly different.

\subsection{Research in Religion on the Political Agenda}

There was a political question at the outset of the programme. The heightened public presence of religion - the "return of religions" in the public sphere (Oelmüller 1984) — seemed to constitute an important motivation for developing such a broad research programme. The fear of a 'clash of civilisations' (Huntington 2011) in Swiss miniature format which would threaten social cohesion, or at least present a prospect of attenuated interreligious conflicts in Switzerland seemed to have represented a negative incentive to install the aforementioned research programme. Swiss society relied for a long time in distinct ways on civic religion mostly fuelled by Christian traditions and the legacy of the Enlightenment. In the wake of a new cultural and religious context, these cultural values seem to become increasingly contested by the erosion of the Christian tradition, by competing "foreign" religions and by different cultural ways of life, values and norms connected to the religious background of immigrants. Should the state regulate the relations between religious communities in this context differently than it did before? Is there a stronger need to secure freedom of religion and freedom for religion (as long as the basic tenets of democratic societies were not called into question)? Are the implications of religious neutrality different in a context where the societal consensus about what exactly constitutes religion disappears? And what does this neutrality mean, anyway?

Neutrality of the state in religious affairs in Switzerland never meant a strict religious abstinence and no involvement whatsoever of the state with the Churches. The separation between Church and state has never been interpreted in the French sense of a strict laicité where any association between the secular government and religiosity is taboo. Neither could one speak of a "wall of separation" in which any kind of direct or indirect support is strictly forbidden. Instead, a more cooperative neutrality has been the guideline for the Swiss state in its relations with the Churches and different confessions. A positive and open (Pahud de Mortanges) neutrality has been a hallmark of Swiss religious policy over the last two centuries. This stance is the historical result of reactions to deep religious conflicts threatening the very survival of the Swiss Federation of cantons with their specific confessional priorities until the middle of the 19th century. However, it seems that this understanding

Approaches to Law and Society' funded by European Commission Directorate General Research (www.religare.eu). 
of religious neutrality is both questioned and reactivated due to mounting religious plurality in Switzerland. Different existing regulations in which the state's and the Churches' interests are finely balanced - the government's school policies is a prominent example - are now under discussion. While the historical preference for certain denominations in specific cantons has come under pressure, at the same time, the political authorities look for new ways of living up to the ideal of this so-called positive and open neutrality of the state.

The National Research Programme Religion, the State and Society (NRP 58) in fact mirrors this position of the state with regard to religion. In some respects, it can be read as an example of positive religious neutrality. This neutrality has to become a 'visionary neutrality' in the midst of a radically changing religious scenery. Such a 'visionary neutrality' should envisage ways for social stability and societal cohesion, independent of the religious differences among the Swiss inhabitants. Science is credited with the power to foster knowledge, enabling the state to define its religious neutrality anew in a situation that might threaten this social cohesion, as the religious wars between Catholics and Protestants once did in past centuries.

It is interesting to observe how the subtle balance between the freedom of research and the state's interest in research that has the potential for considerable political impact was handled in the NRP 58. On the one hand, the state provided the necessary institutional frame and funding of the research programme without interfering in the development and evaluation of specific research proposals itself. On the other hand, National Research Programmes are an approved way of dealing with public interests through independent research. The research scheme of NRP 58 illustrates this ambiguity. It was made clear from the outset that religion should not be analysed as a discrete social system bound by its own inner logic. Research in the programme had to look empirically and analytically at how far and in which ways religion in late modern society interacts with different public spheres such as economics, politics, law, media, health care and education. The structure of NRP 58 in different research modules guaranteed the coverage of different public spheres. In addition to scientific disciplines traditionally associated with the study of religion (theology and religious studies), disciplines such as sociology, political sciences and communication and media studies were added to analyse the interfaces of religion and public domain (14 of the 28 research projects originate in these disciplines). ${ }^{3}$

${ }^{3}$ Not part of the parcel was psychology of religion, a discipline with a long empirical tradition, but maybe, with its focus on individual aspects of religiosity, with limited capacities to analyse the societal problems described in the research modules. 
In other words: the programme itself reflects the changed presence of religion in the public domain. It illustrates the (renewed) interest of the state in the public significance of religion, as well as in a reflection on a positive religious neutrality of the state.

\subsection{Moving beyond Traditional Models of Analyzing Religion in Today's Society}

Thus, this interdisciplinary research programme opened new possibilities for research on religion in Switzerland. Over the last thirty years, sociology of religion has been the leading discipline in researching the changes of Switzerland's religious landscape. But the interdisciplinary endeavour of the NRP 58 to research religion, in its private and public manifestations, was new and unique. Scientific disciplines such as political science, social anthropology, media studies and economics "discovered" a field of public interest that hitherto had not been part of their main research traditions. This sensitisation of a broad range of scientific disciplines for religious issues was one of the aims of the programme. The presence of religion in the public realm calls for scientific approaches capable of developing research on the interfaces of religion, state and society, on the politics of symbols and collective imagery, the complex relationship of religion to the public sphere, the economic give and take connected to religion and its institutionalisations. Not all the projects from these disciplines could refer to an established research tradition regarding religion, nor to clarified concepts and an ongoing scientific discourse on religion. Discussions between the different research projects, in particular between projects in theology and religious studies on the one hand, and those in disciplines which do not necessarily have religion as the object of their study on the other hand, were rather scarce. In this sense, the interdisciplinary nature of the research programme was a strength but also a weakness.

Another striking feature of the programme is connected to this shift. Theories of secularisation and de-secularisation, which often form the vantage point within contemporary sociology of religion, were far from being the dominant perspective in the development of the programme, neither in the selection of the research proposals nor during the research itself. Within NRP 58, approaches rotating around the issues of secularisation were not leading in the social-scientific research on religion. Instead, the panel of research projects of the NRP 58 resembles more a collage of very different approaches to religion, with different methodologies, smaller-range theories and with a striking presence of qualitative research. In this respect, the programme seems to mirror again in some way the changed presence of religion in the public life of Switzerland. It does not support a "sovereign line of analysis" of the presence of religion, building on sociological secularisation and de-secularisation theories, 
as Woodhead $(2012,27)$ concludes after her analysis of a parallel national research effort in the United Kingdom, "but it allows new interpretations to emerge, quieter voices to be heard, everyday lives and struggles to count, and conflicts and unintended consequences to be taken more seriously".

\subsection{The Scientific and Societal Relevance of Defining Religion}

The NRP 58 was initiated under the label: "Religion, the State, and Society". For a while, a second heading of the programme was "Religions in Switzerland". This subtle difference in the title of the programme and the oscillation in the perception of what it really dealt with points to a deeper problem. What is the actual material object of this research programme? Does it deal with 'religion' or 'religions' in Switzerland? Although this question could at first sight be considered as highly speculative without many societal consequences, the answer to this question is also bedevilled by normative claims and ideological principles. Straightforward free association makes this already clear: while the first category — 'religion' — seems to take the religious individualization for granted, the latter — 'religions' — can be related more easily with institutionalised religious traditions as the object of study. What is more, many of the projects showed that different definitions are part of the political struggles around religion. To take an example: it matters for religious education at schools whether religion is conceptualized as a strictly individual affair or (also) as a more or less institutionalised set of convictions with a considerable impact on the (lack of) cohesion of society. Whether 'religion' or 'religions' should be the focus of study can be asked on many different levels. First, clarifying the definition of 'religion' was an important task for the individual research projects. What is studied exactly? How should religion be understood and operationalized? Second, defining the object of study was a problem for the programme as a whole, as the two different titles of the programme already show. Is it research on the different religious traditions with their particularities in Switzerland or is it research on the interfaces of religion in general, state and society. And if the latter is the case: is it the 'religion' of individuals or the 'religion' of groups of individuals? In a way, Taves' statement on 'religion' as object of study in the humanities at universities also holds true for the programme: "In stipulating definitions, we tacitly acknowledge and attempt to get around the underlying problem that is dogging us: the historical instability of our object of study. What we and our subjects refer to as religion, religions, traditions, the sacred, magic, the occult, superstition, folk beliefs, fetishes and so on implicitly embed claims about what is, or ought to be valued. These claims, more often than not, can be located at sites of struggle where people contest the meaning of events and make claims about what matters most in 
the overall scheme of things" (Taves 2011,290). In a research programme that is expected to produce findings of practical relevance to both government offices and public administration this becomes even more clear than in research in the ivory tower. The problem of what religion "really" is, cannot be settled only at the level of scientific definitions trying to demarcate the object of study. Defining religion has societal implications. It was chosen as a topic of a national research scheme precisely because of this. How we define religion ('material object') and the way we study it ('formal object') is related to power struggles in society on what should be the means ('the purposive') for realising what we consider the ultimate good and what we consider as right. It can be assumed that research on 'religion' opens up possibilities for rendering thematic issues with political relevance that are not otherwise accessible (cf. Habermas 2008, 114-147).

\subsection{Globalisation and Religion in the National State}

The NRP 58 also pointed to the impasse of a research programme in religion in one single country. We no longer live in an era of isolated nation states with their own particular religious landscape. In addition to modernisation, secularisation and migration, Swiss society is also faced with the phenomenon of globalisation greatly influencing religion. Globalisation refers to the growing scale and frequency of cross-border contacts. It is a matter of increased and intensified contacts between people, population groups and cultures, as a result of which they are absorbed into global dependency networks. Two factors have contributed notably to globalisation. Firstly, the emergence of modern means of communication has given rise to a flood of information accessible world-wide. As a result, knowledge of previously "alien" traditions has grown. Secondly, increased mobility has enabled many people to have contact with foreign cultures. If not at home, we get acquainted with other cultures when we are spending time elsewhere.

We do not deal here with the economic, political, social and cultural dimensions of globalisation (Ritzer \& Atalay 2010). But when discussions in these societal domains are accompanied by reflection on divergent patterns of norms and values, it surely promotes awareness of multiculturalism. Hence, the emergence of global dependency networks is also of great significance for religion. Next to other factors, globalisation has led to an increased awareness of religious plurality. Despite its pluriformity, the meaning-giving systems in our Western culture deviate considerably from the frames of reference used by 'new' inhabitants and the 'new' cultures that people encounter. The conditions under which meaning is constituted are no longer uniform and collective. In a globalised world, individuals lump together elements of diverse orders of 
meaning in order to devise their own process of constituting meaning. Globalisation has, in other words, given further impetus to the awareness of religious plurality, as well as to the changed conditions in which individuals construct meaning (cf. Hvithamar et al. 2009; Turner 2011, 224ff).

Due to the existence/influence of globalisation a national framework of research should not turn a blind eye to the influence of worldwide developments on religion. Whereas previously attention was mainly given to the relation between religious communities and the nation, in the wake of globalisation, research on religion in a national context also needs to pay attention to developments outside the country concerned. And, conversely, one could also ask how research in national contexts could add to the understanding of religion in a global world. Religion, while often lived locally, like any other manifestation of culture has to be understood in relation to global dependency networks. In this way, a national research programme, like the NRP 58, does not only take the wider context into account, but can also add to our understanding of what globalisation means for religion.

\subsection{Overcoming 'Ecclesiastical Captivity'}

Many of the projects of the NRP 58 were promoted by religious studies. Only a few theologians took part, who were either members of interdisciplinary teams or were involved in projects with a social-scientific approach. Eleven out of twenty-four proposals submitted by researchers in religious studies were selected, while only two out of eighteen proposals by theologians could be realised. This may well be because of the doubtful quality of the theological projects submitted originally. But the choice of projects by the selection committee may also reflect changes in the hierarchy of scientific disciplines perceived as capable of analysing religion and its public significance. It is no secret that elsewhere in Europe, theological scholars are also poorly represented in broad research programmes focusing on religion (e.g. in the research programmes mentioned in the footnote above). But let us limit the discussion here to the only two theological projects in the Swiss NRP 58: What does it say that the practical-theological discipline of pedagogy of religion is not included in a research project on 'religious education in schools'? Or how to interpret the absence of pastoral counselling theory in research on spiritual care and 'religious pluralism in Switzerland's prisons'?

NRP 58 reflects a shift in the scientific research on religion from theology to other disciplines. But does it also actively promote such a shift towards other disciplines studying religion? Surely, many in the academic community look at theology with a certain suspicion. In a number of countries there is increasing ecclesiastical control of theology, which is often accompanied by 
marginalisation of theology at universities. To overcome what Linda Woodhead, paraphrasing Thomas Luckmann, refered to as 'ecclesiastical captivity'4 was without doubt an influential subtext on the NRP 58. Theology is seemingly associated with looking at religion 'from within', and is even suspected of following a hidden agenda, whereas disciplines with a social-scientific approach to religion 'from the outside' are considered more neutral. To say the least, there appears to be no consensus whether theology offers the best institutional context in which religion can be studied at an academic level. What, then, is the perception of theology (cf. Sterkens 2009)?

To some people, theology remains the primary discipline for studying religious culture, but the views on its broad goal orientation vary widely. According to some, theology aims at expounding and actualising (the official doctrine of) the tradition in which it is embedded. Although theology applies logic and rationality in the process, ultimately, its motivation is considered apologetic. How to interpret 'apologetic' is again debatable. It may mean, for example, that theology seeks to legitimise and explain a faith and its practices. Even if theology - whether viewed in this perspective or not - serves the cause of a particular religious tradition and its institutions, it still seeks to perpetuate that tradition (e.g. Turner 2005). In a more liberal sense the term 'apologetic' implies looking for the rationality of a specific religious tradition in its own perspective, which could entail clarifying its ideas. In changing times, therefore, perpetuating a religious tradition means it has to be transformed. But even more rational interpretations of theological duties contain tensions, as Habermas makes clear: "With an at once critical and apologetic intention, it [modern apologetics centered on the Catholic philosophy of religion] brings about the internal rationalization of a religious heritage (alongside modern theology) with the aim of finding a satisfying dogmatic answer to the challenges posed by modern religious pluralism, the scientific monopoly on knowledge, and the constitutional state." This is a definition of the theologian's task that inherently contains certain contradictions, as Habermas points out elsewhere: "Against religion, the democratic common sense insists on reasons which are acceptable not just for the members of one religious community. [...] The scientistic belief in a science which will one day not only supplement, but replace the self-understanding of actors as persons by an objectivating self-description is not science, but bad philosophy" (Habermas 2006, 108).

42009 in a conference of the programme at Fribourg. Woodhead referred to the first chapters of Luckmann's "Invisible religion" (Luckmann 2010), where Luckmann criticises sociology of religion for being 'captive' - i.e. using value-laden concepts without even realising it, and therefore without the possibility of being self-critical. 
Others will consider the view that theology as a science 'serves the cause' of a particular religion to be scientifically anachronistic. Theology as currently done at many universities is an academic discipline functioning for the most part autonomously of the institutions of the religious tradition(s) with which it is associated. It has become the cultural science of Christianity or theory of religion (Lübbe 1997). Nonetheless this leaves open the possibility, if not indicating the unavoidability, of other (than theological) forms of scientific study of religion. Particularly, inasmuch as the evaluation of religious traditions and their truth claims forms part of the scientific enterprise, the comparison of different traditions (in terms of a meta-theory) is essential. Comparison here is seen as a vital condition for, rather than an obstacle to, normative judgment (cf. Wils 2006). Some feel that religious studies is more amenable to such an exercise than theology.

Notwithstanding academic theology's self-understanding as a scientific discipline bound to reason and methodological rigour, it seems to be perceived in a different way. As the Churches are no longer seen as the main institutions through which religion is governed in Swiss society, theology might be perceived as manifesting an 'ecclesiastical captivity' and consequently be discarded as a scientific discipline.

\subsection{Values and Norms as Research Topics with Political Implications}

The reflection of new legal regulations on the relations between state and different religious communities on its territory was one of the main political interests leading to the research programme. Some basic research questions of NRP 58 were therefore related to legal issues touching basic normative tenets of civil society. Interestingly enough, a few projects by researchers in the faculty of law were submitted, but none were accepted. Juridical expertise had to be incorporated in the NRP by specific invitation. Still, questions about values and norms related to religious traditions or the religious convictions of individuals were extensively reflected upon. Although legal regulations do not stem naturally from values and/or social norms, values and norms do play a role in the construction of law (Drobak 2006). The complex relation between the law and what is inelegantly called "nonlegal mechanisms of cooperation", such as norms and values in relation to religion, was studied within NRP 58 (cf. Posner 2002, 5). Let us give two examples. Firstly, the way values and norms are intertwined with lived religion was studied in a project lead by Morgenthaler \& Käppler. They examined the partial and conditional relevance of religion and value orientations for the emergent identities and mental health of adolescents (cf. Bockle et al. in this volume). Secondly, linked to the public interest of controlling impending conflicts between religious communities 
and of restricting harmful forms of religion was the issue of perceived (and conceptualised) differences between "good" and "bad" religion (cf. Plüss in this volume).

The question of the political and legal implications of the research findings surfaced more strongly towards the end of the NRP 58. The relation between religion and values was set as one of the leading questions for integrating the results of the different research projects. Evidently, the formation, transmission and 'canonisation' of values and norms is a basic challenge of a research programme analysing the declining power of religions. To secure a horizon of values promoting the peaceful cohabitation of people, groups and religious communities is a big challenge indeed. The complex relations between normativity and scientific research that have haunted the social sciences from their beginnings have become, therefore, virulent anew in a research programme on religion and its political implications. The perspective "from the outside", too, is intermingled in many ways with questions about the "common good". Thus, the research programme sets the problem of normative reflection strongly on the agenda of social-scientific research of religion. Without critical reflection on the normative traditions connected to religion, and without critical reflection on the normative implications of applied social-scientific research of religion, 'ecclesiastical captivity' could easily be supplemented by 'state captivity', that is, by an unreflected binding of the research of religion to political interests.

Unsurprisingly, political discussions ongoing during the period of the research programme (e.g. public vote on minarets) and the research itself were related in many ways. This yielded a heightened attention for the results from, and controversies about, projects of the NRP (e.g. university education for imams, the declining importance of the Churches). But this touches a deeper problem. The religious situation in Switzerland with its political implications was both reflected in and refracted through the research programme. To take an example, the focus of research on Muslims in a specific research module yielded deepened knowledge of an underprivileged religious group in Swiss society. But this focus was also questioned as a duplication and reinforcement of the heightened public attention for Muslims as a problematic or even dangerous group in Swiss society. The programme showed the necessity of a closer study of the interface of research in religion and the day-to-day politics of a nation, a problem hitherto hardly dealt with, as well as a new reflection on research priorities, their interest-laden character and their complex relations to political controversies in the public. 


\subsection{Piecing together the Puzzle}

How can the results and perspectives of the 28 research projects be integrated? Similar to other steering committees of National Research Programmes, NRP 58 struggled with this question towards the end of the programme. The synthesis of the research programme "Religion, the State and Society" is anything but trivial. It entails more than submitting summaries of the main research findings to a central authority, which then presents them altogether on its own terms. Integration implies more than bargaining over which findings are important enough to enter a final report. In the words of Bloom's taxonomy (Bloom 1956): a synthesis compiles information together in a different way by combining elements in a qualitatively new pattern. Synthesis enables people to propose alternative solutions for complex problems. Integration of research results, then, supposes combining diverse structures, forms or functions under more abstract umbrella concepts. It allows spotting relationships between more and more elements, which can then be combined in a complex whole. Through progressive organisation and establishing relations between concepts we can structure heterogeneous phenomena into coherent wholes. This frame of reference in fact consists in structuring an ever more differentiated reality through increasing conceptualisation, organisation and hierarchical arrangement of concepts (cf. Van Haaften et al. 1997). In addition, the usability of scientific knowledge generally requires the combination and integration of knowledge from various scientific disciplines as well. This touches on a basic problem: is there a scientific stance from where such an integration could be done? What theory can be leading? Which scientific discipline, if any, is able to accomplish this Herculean task?

The logic answer is, of course, that there is no single discipline that is able to accomplish such an integration. Research on religion implies multidisciplinary, interdisciplinary, and transdisciplinary endeavours, as well as critical reflection on the normative decisions implied in piecing together the puzzle. Without trying to define the concepts of 'multidisciplinarity', 'interdisciplinarity' and 'transdisciplinartiy' in too much detail, the basic difference consists in the level of integration of the different disciplinary approaches they are based on. A multidisciplinary approach brings experts from diverse disciplines together to collectively address a complex problem, each from the perspective of his or her own discipline. An interdisciplinary approach is what results from the melting of two or more disciplines to create a new (interdisciplinary) science. It creates its own theoretical and conceptual identity, as well as a common methodology. And a transdisciplinary approach goes even one step further by establishing a common theoretical understanding, accompanied by 
a mutual infiltration of disciplinary epistemologies (Gibbons et al. 1994; Van den Besselaar \& Heimeriks 2001). But in all these models, a dialogue between (representatives of) different scientific disciplines is the best way of finding integrative perspectives. That interaction may range from communication and comparison of ideas and the exchange of methods and procedures, over the mutual integration of organizing concepts, theories and methodology, to the establishment of common epistemological principles (Thompson 1996; cf. Shafranske 2011). This integration in fact happened to a certain degree in the National Research Programme discussed in this special issue of JET. The steering committee of NRP 58 engaged those involved in the different research projects to look at different research disciplines from the beginning of the programme onwards. This is not an easy task, since the institutional organization of our sciences in universities is dominantly based on disciplinary distinction. Research possibilities are mostly given and stimulated within the limitations of these disciplines. And careers are also made within this system. However, when research results are socially relevant and should be made applicable, integration of different disciplines is necessary.

What is the role in this process of the disciplines which have religion as their explicit study object, namely religious studies and theology? It is difficult to answer this question without going into detail on the different subdisciplines of religious studies and theology. Scholars who found their scientific home under the roof of faculties (or departments) of theology and/or religious studies already have very different methodologies. But at least one can say this: religious studies has developed systematic concepts and tools for the analysis of texts and practices of different religious traditions as well as for the analysis of a large array of today's religious expressions. Notwithstanding its image, theology would be also a candidate for this task, in close cooperation with religious studies. What theology could add to this dialogue is specific knowledge about Christian faith and its manifestations in history and contemporary societies. It could add its own experience of dialogue between its own philological, historical, systematic and practicaltheological sub-disciplines. And it could point to the normative presuppositions lurking in supposedly 'neutral' scientific research and programmes and could initiate discussion about the normative foundations of empirical research on religion.

\subsection{Implementing the Results or just Coming to a Close}

The National Research Programme 58 'Religion, the State and Society' comes to a close in 2011. Generating knowledge with practical relevance is one of its 
main goals. This is in itself a task containing many conceptual, theoretical and practical problems. Just to mention a few: research findings on religion should inspire new practices in state and society. Practices, however, cannot be developed without defining desirable goals, something that involves normative reflection. A communication strategy (in cooperation with a public relations agency) is part of NRP 58 in order to increase the societal impact of the programme. The distribution of the research results to the general public is furthered by the publication of books summarizing the results of the whole programme, by circulating booklets presenting the results of modules or specific projects, by funding conferences, and — last but not least — by training scientists in communicating with the media. But who will decide how the results are perceived and put into use, once they have become part of the public discussion? Scientists have got hardly any power to control this process of perception and reception of their work. To make scholars more aware of the 'valorisation' of their insights, the Swiss Research Foundation has developed tools to measure the impact of their scientific research evaluating publications and influence on future research. Implementing research findings in practical and concrete activities is in itself a challenging task. One could, for instance, think about giving advice on new laws and regulations, the organisation of programs stimulating good relations between religious communities, or the involvement of policymakers in order to make them critically aware of conditions conducive to the radicalization of religious identities. How to implement research findings in practice would in itself already be an interesting topic for a next research programme.

Practical theology could also contribute in a well-reflected way to implementing the results of this programme. We have already mentioned some reasons why it was left aside. Generally, it can be suspected that social-scientific knowledge about religions in Switzerland gained through research cannot be absorbed easily by the Churches and by theological research. This is even the case when the Churches themselves initiate such research. To take but one example, Stolz's analysis of the future of the protestant Churches in Switzerland - according to the prognosis the protestant Churches will loose 35\% of its members in the next 40 years (Stolz \& Ballif 2010, 13) - encountered strong objections. Integrating the results of the NRP 58 into Church practice is an even more delicate issue. Of course, putting research (and research results) into question is part and parcel of the scientific enterprise. However, research results can be politically sensitive for the Churches. It is understandable, therefore, that Church leaders are sometimes afraid of the consequences of public attention to research results which are not exactly flattering for the prospects of their organisation. In addition, it is not easy to implement research results 
when the fulfilling the tasks of the Churches, for a start, since theological faculties were only marginally involved in the research. Lack of cooperation, or — in some places - even conflicts, between theology and religious studies backfired on theology once this cooperation was settled. The results of the NRP 58 could and should be an inspiration for a public theology in Switzerland that is yet to be developed.

\section{Conclusion}

A research scheme depicting relevant areas of interest, 28 single studies focusing on specific religious topics, a continuing effort to relate the approaches und results of theses studies and — last but not least - a state which initiates, funds and values research of religion, these were the hallmarks of the NRP 58 in Switzerland. It offered unique possibilities for charting today's religious territory from new perspectives, for sensitizing scientific disciplines hitherto only marginally interested in religion and its continuing presence and for initiating interdisciplinary cooperation in order to arrive at a multifaceted picture of the impact of religion in different areas of social, public, political and cultural life. Programmes such as the NRP 58 surely point in the direction that research of religion should find its way in future.

There are also limits to be mentioned, of course. The programme will not be repeated. Longitudinal research — of specific interest also in the study of religion which is so intimately interwoven with developing social contexts, politics, globalisation and historical changes - cannot really be supported in substantial ways within the framework of a time-limited programme. Research is also limited by the national context which has to be respected. The religious landscapes of different societies, therefore, cannot directly be compared. Also limited are the possibilities for applying research results in effective societal praxis. With the end of the programme, the holding and inspiring environment for a concerted scientific effort to understand better the impact of religion and religions in contemporary Switzerland breaks away and it is up to the single disciplines whether religion will be the object of continuing research or whether the topic shifts back to the fringes of interest.

Programmes such as the NRP 58 are also of considerable importance for theology. The standing of theology as an academic discipline is of course not solely dependent on the capability to join such a programme. But it surely affects theology whether it is perceived to be worthy and capable of contributing to a deeper understanding of religion in today's European societies. The impending marginalisation of theology even in the domain of its main research competence is urging the theological disciplines to position themselves in a 
new way. The capability of conducting empirical research is one of the main prerequisites for projects to be approved in a programme such as the NRP 58. In that sense, it is not difficult to see that empirical methodology plays an important role in guaranteeing the presence of theology in the scientific community of the social sciences. It is indeed key not only to financial funding but also to public discourse. There is yet another benefit to this stance. Theology's discrete charm for scientific research on visible and invisible religion could become visible again. As a scientific discipline, it combines in unique ways empirical research with historical and systematic reflection of religion. And it guarantees in similar ways to religious studies a continued research interest in religion and religions, long after the bells have rung the end of a programme.

\section{References}

Bloom B.S. (ed.) (1956). Taxonomy of educational objectives. The classification of educational goals. Handbook I: cognitive domain. New York.

Bovay C. \& Broquet R. (2004 [2005]). Eidgenössische Volkszählung 2000. Religionslandschaft in der Schweiz. Neuchâtel: Bundesamt für Statistik (BFS).

Bradley S. (2010). Neuchâtel church tax goes up in smoke. 5 December 2010. Swissinfo.ch (retrieved 01-10-2011).

Church C.H. (2004). The politics and government of Switzerland. New York [etc.]: Palgrave Macmillan.

Drobak J.N. (ed.) (2006). Norms and the law. Cambridge/New York [etc.]: Cambridge University Press.

Gibbons M. et al. (1994). The new production of knowledge. London: Sage.

Habermas J. (2006). Faith and Knowledge. In: The Future of Human Nature. Cambridge/ Malden: Polity Press. p. 101-115. Translated from the German: Glauben und Wissen. In: Friedenspreis des Deutschen Buchhandels. Frankfurt am Main: Suhrkamp Verlag. 2001.

- (2008). Between naturalism and religion. Cambridge: Polity Press. Translated from the German: Zwischen Naturalismus und Religion: Philosophische Aufsätze. Frankfurt amMain. 2005.

Hvithamar A., Warburg M, Jacobsen B.A. (eds.) (2009). Holy nations and global identities. Civil religion, nationalism, and globalisation (International Studies in Religion and Society). Leiden: Brill.

Huntington S. (2011). The clash of civilizations and the remaking of the world order. Updated edition. London [etc.]: Simon and Schuster.

Lübbe H. (1997). Theologie als christliche Kulturwissenschaft. In: Krieg M. et al. (eds). Universitas in theologia - theologia in universitate. Zürich. pp. 43-50.

Luckmann, T. (2010). Die unsichtbare Religion. 6. Aufl., Frankfurt/M.: Suhrkamp.

Oelmüller W. (1984). Wiederkehr von Religion? Perspektiven, Argumente, Fragen. Paderborn: Schoning.

Posner E. (2002). Law and social norms. Harvard University Press.

Ritzer G., Atalay Z. (eds.) (2010). Readings in globalization. Key concepts and major debates. Cambridge [etc.]: Wiley-Blackwell. 
Rutz G.A. (2001). Church autonomy and religious liberty in Switzerland. In: Robbers G. (ed.). Church autonomy: a comparative survey. Frankfurt am Main: Peter Lang.

Shafranske, E.P. (2011). Afterword. Integration or dialogical turn? In: Noth, I., Morgenthaler C., Greider K.J. (eds.) (2011). Pastoralpsychologie und Religionspsychologie im Dialog/Pastoral Psychology and Psychology of Religion in Dialogue. Stuttgart: Kohlhammer. pp. 236-237.

Sterkens C. (2009). Educational Goals in Theology and Religious Studies. A Comparison Between University and Secondary School Education in Europe. In: Ziebertz H.-G., Riegel U. (eds). How teachers in Europe teach religion. An international empirical study in 16 Countries (International Practical Theology 12). Münster [etc.]: Lit Verlag. pp. 257-274.

Stolz J. \& Ballif E. (2010). Die Zukunft der Reformierten. Gesellschaftliche Megatrends - kirchliche Reaktionen, Zürich: Theologischer Verlag Zürich.

Stolz J., Könemann J., Purdie M.S., Engelberger T., Krüggeler M. (2011). Religiosität in der modernen Welt. Bedingungen, Konstruktionen und sozialer Wandel. Lausanne: Observatoire des réligions en Suisse.

Taves, A. (2011). 2010 Presidential Adress: "Religion" in the Humanities and the Humanities in the University. In: Journal of the American Academy of Religion 79 (2011). pp. 287-314.

Thompson K.J. (1996). Crossing boundaries: knowledge, disciplinarities, and interdisciplinarities. University Press of Virginia.

Turner B.S. (2011). Religion and modern society. Citizenship, secularisation and the state. Cambridge: Cambridge University Press.

Turner D. (2005). Doing theology in the university. In: Ford D.F., Quash B. \& Soskice J.M. (eds). Fields of Faith. Theology and Religious Studies for the Twenty-first Century. Cambridge: Cambridge University Press. pp. 25-38.

Van den Besselaar P. \& Heimeriks G. (2001). Disciplinary, Multidisciplinary, Interdisciplinary. Concepts and Indicators. Paper for the 8th conference on Scientometrics and Informetrics, Sydney — Australia, July 16-20, 2001.

Van Haaften A.W., Korthals M., Wren T. (ed.). (1997). Philosophy of development. Reconstructing the foundations of human development and education (Philosophy and Education 8). Dordrecht/ Boston/London.

Wils J.-P. (2006). Religion als Gegenstand der Wissenschaft — welcher Wissenschaft? Über letzte Worte als vorletzte Worte. In: Freiburger Zeitschrift für Philosophie und Theologie 53 (2006-3), pp. 659-680.

Woodhead L. (2012, forthcoming). Introduction. In: Woodhead L., Catto R. (eds.). Religion and Change in Modern Britain. London: Routledge. pp. 1-33. 